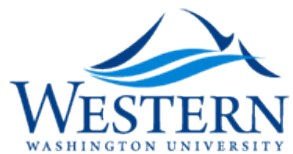

Western Washington University Western CEDAR

$8-1991$

\title{
Contributions to Children by Divorced Fathers
}

Jay Teachman

Western Washington University, jay.teachman@wwu.edu

Follow this and additional works at: https://cedar.wwu.edu/sociology_facpubs

Part of the Sociology Commons

\section{Recommended Citation}

Teachman, Jay, "Contributions to Children by Divorced Fathers" (1991). Sociology. 10.

https://cedar.wwu.edu/sociology_facpubs/10

This Article is brought to you for free and open access by the Social and Behavioral Sciences at Western CEDAR. It has been accepted for inclusion in Sociology by an authorized administrator of Western CEDAR. For more information, please contact westerncedar@wwu.edu. 


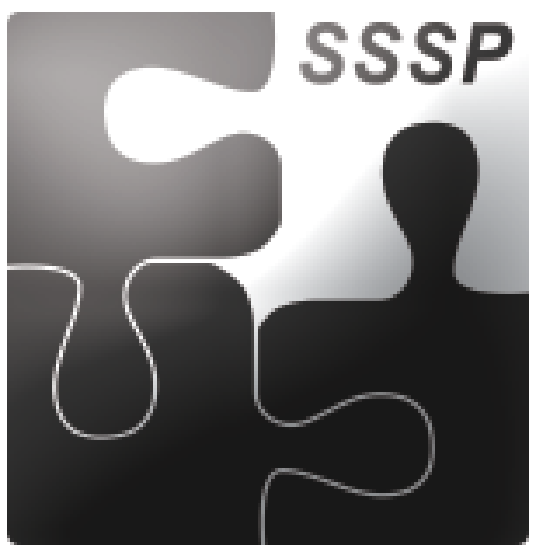

\section{Contributions to Children by Divorced Fathers}

Author(s): Jay D. Teachman

Source: Social Problems, Vol. 38, No. 3 (Aug., 1991), pp. 358-371

Published by: University of California Press on behalf of the Society for the Study of Social Problems

Stable URL: http://www.jstor.org/stable/800604

Accessed: $21 / 01 / 2015$ 13:52

Your use of the JSTOR archive indicates your acceptance of the Terms \& Conditions of Use, available at http://www.jstor.org/page/info/about/policies/terms.jsp

JSTOR is a not-for-profit service that helps scholars, researchers, and students discover, use, and build upon a wide range of content in a trusted digital archive. We use information technology and tools to increase productivity and facilitate new forms of scholarship. For more information about JSTOR, please contact support@jstor.org. 


\title{
Contributions to Children by Divorced Fathers*
}

\author{
JAY D. TEACHMAN, University of Maryland
}

\begin{abstract}
Beyond the payment of child support, relatively little is known about the nature and extent of contributions of divorced fathers to their children. Using nationally representative data from a sample of ever-divorced women taken from the National Longitudinal Study of the High School Class of 1972, the nature and extent of various forms of assistance (in eight areas) provided by divorced fathers are examined. The majority of fathers seldom or never make contributions to their children. Fathers who do contribute to their children have more economic resources and enjoy better relationships with the custodial mother. In addition, there is little support for the notion that fathers substitute other forms of assistance for payment of child support. Rather, other forms of support are provided in addition to making child-support payments.
\end{abstract}

Concern over the consequences of marital disruption has spurred considerable research, documenting the negative consequences of marital dissolution for female-headed families (Garfinkel and McLanahan 1986; Hoffman and Duncan 1988) and the long-term negative consequences for children (McLanahan and Bumpass 1988). At least part of the negative impact of divorce on women and children can be traced to the loss of economic support from fathers. Specifically, women with children experience a 30 percent decline in income in the first year following divorce (Hoffman and Duncan 1988), and divorce accounts for many women falling below the poverty line (Lerman 1987).

Historically, as it has evolved through the political and legal systems (Kahn and Kamerman 1988), the central mechanism by which divorced fathers contribute to their children has been court-ordered child-support payments. Yet, recent estimates indicate that nearly 20 percent of divorced mothers do not have a child-support award (Office of Child Support Enforcement 1988). Moreover, of women with an award, less than 75 percent receive payment, and the amount of support received is generally below the costs associated with rearing children (Beller and Graham 1985; Seltzer 1991). Recognizing the centrality of child-support payments for the economic well being of children following divorce and the variability in child-support outcomes, considerable research has sought to identify the correlates of child-support award and receipt, as well as the amounts involved (Beller and Graham 1985, 1986; Hill 1984; O'Neill 1985; Peterson and Nord 1988; Seltzer and Garfinkel 1990).

However, almost nothing is known about other forms of social and economic contributions fathers make to their children. In addition to making child-support payments, fathers can provide economic contributions by purchasing clothing for their children or by assuming medical and other expenses, resulting in increased material well being of their children. Such economic contributions also imply greater involvement on the part of fathers as they gather information about their children (likely through increased contact) and make decisions about how much to contribute, when to contribute, and in which areas.

Fathers can also elect to participate more or less fully in their children's daily activities, for example, taking an active interest in their children's schooling. Although the roots of the

* This research was supported by funds provided by the Institute for Research on Poverty at the University of Wisconsin, NSF grant SES-8812215, and a Semester Research Award from the University of Maryland. Research conducted at the Center on Population, Gender, and Social Inequality is facilitated by a grant from the William and Flora Hewlett Foundation. Correspondence to: Teachman, Center on Population, Gender, and Social Inequality and Department of Sociology, University of Maryland, College Park, MD 20742-1315. 
effects are not entirely clear, children from divorced families are more likely to drop out of high school, experience disciplinary problems in school, and engage in delinquent behavior (Hetherington, Cox, and Cox 1979; Matsueda and Heimer 1987; McLanahan 1985). These outcomes may be due partly to the lack of participation and supervision on the part of fathers.

Given the paucity of empirical evidence, the first goal of this paper is to describe the nature and extent of contributions fathers make to their children, including child-support payments, but with greater emphasis on other forms of assistance. The second goal is to estimate the relationship between selected variables and these contributions.

The third goal is to ascertain the degree to which fathers who provide one form of assistance are likely to provide other forms, with particular attention to competing hyphotheses about the association between child-support payments and other contributions. One hypothesis holds that contributions are positively correlated because divorced fathers who pay child support are more likely to have contact with their children (Furstenberg et al. 1983; Seltzer, Schaeffer, and Charng 1989). Fathers who have contact with their children have both the information and opportunity needed to provide other forms of assistance.

The alternative hypothesis holds that fathers opt to substitute, not supplement, other forms of assistance for child-support payments. This occurs because fathers cannot control how the payments are divided between the personal consumption of the custodial parent and the children (Weiss and Willis 1985). Congruent with reports from divorced fathers, inability to control how child support is allocated by the custodial mother might be a primary reason for not making payments (Haskins 1988). By examining the relationship between child-support payments and other forms of assistance, it is possible to test whether they are substitutes or complements.

\section{Data}

The data are taken from the fifth round of the National Longitudinal Study of the High School Class of 1972 (NLS). The NLS has followed respondents from their senior year in high school to early 1986, with intervening follow-ups in 1973, 1974, 1976 and 1979. The original sample was a stratified random sample of all high-school seniors enrolled in public, private, and church-affiliated high schools in the United States (Tourangeau et al. 1987). The fifth follow-up is a subsample of approximately 14,500 cases of the original sample of over 22,000 men and women and contains a supplement gathering detailed information from ever-married custodial parents about the nature and extent of assistance provided by the other parent. Because very few divorced fathers in the population and thus in the NLS data have custody of their children, analyses are based on responses provided by mothers.

Respondents in the NLS are followed from approximately age 18 to age 32 , a span of ages over which both marriage and divorce are likely to occur. However, disruptions of late marriages (those that occur after age 32) and marriages of long duration (more than 14 years) are not observed. Also, women divorced after age 32 are not included. However, the ages covered in the NLS are those at which parents are likely to have minor children. All divorced mothers in the NLS are included in the analysis, yielding a sample size of 644 .

To determine the nature and extent of assistance provided by fathers, mothers were asked how regularly the spouse provided assistance with: clothes, gifts, vacations, dental care, medical insurance, uninsured medical expenses, help with homework, and attending school events. They also were asked to report on child support payments.

The use of reports from one spouse (the mother) introduces downward bias into the data. Mothers may underestimate the contributions fathers make to their children for at least two reasons: (1) they lack information about the contributions, or (2) they deliberately downplay the contributions. The first source of bias is likely to be random across mothers, leading to 
conservative estimates of the contributions fathers make but not affecting differences according to the predictor variables.

The second source of bias is more problematic because it is more likely that mothers will downplay the contributions of fathers if their relationship is poor. This type of bias would, therefore, artificially increase reported differences in contributions according to measures of the relationship between the parents. Unfortunately, the data available do not provide any other assessment of the contributions made by fathers. Thus, reported differences according to parental relationship should be interpreted cautiously.

The NLS also misses individuals who were not in school the spring of their senior year in high school. Variation in education and in other variables is thus truncated. However, this restriction is likely to have less impact on ever-divorced mothers because they are more likely than never-married mothers to have graduated from high school. In general, though, the higher education of the NLS sample compared to the United States population means that fathers are more likely to have the resources needed to provide various forms of assistance, most likely leading to an upward bias in the results reported below.

\section{Descriptive Results}

Responses for the regularity with which each type of assistance is provided by fathers are shown in Table 1. Excluding child support, the results indicate that fathers seldom provide

Table 1 - Regularity with which Fathers Provide Each Form of Assistance (percent) $(N=644)$

\begin{tabular}{lrrrrr}
\hline & \multicolumn{5}{c}{ Very Regularly to Never } \\
\cline { 2 - 6 } Form of Assistance & 1 & 2 & 3 & 4 & 5 \\
\hline Pays for clothes & 5 & 3 & 12 & 15 & 65 \\
Pays for presents & 13 & 8 & 20 & 19 & 40 \\
Takes the children on vacation & 8 & 4 & 11 & 11 & 65 \\
Pays for routine dental care & 13 & 3 & 5 & 5 & 75 \\
Carries medical insurance & 28 & 3 & 5 & 4 & 61 \\
Pays for uninsured medical expenses & 12 & 3 & 6 & 4 & 76 \\
Helps the children with homework & 2 & 2 & 5 & 6 & 85 \\
Attends school events & 4 & 3 & 7 & 12 & 75 \\
& \multicolumn{2}{c}{ Regularly } & Occasionally & Seldom & Never \\
Regularity of Child Support Payments & \multicolumn{7}{c}{ 43 } & 11 & 18 & 28 \\
\hline
\end{tabular}

any given assistance. For only one item, purchasing gifts, have more than 50 percent of the fathers ever provided assistance. Except for the provision of medical insurance, which is likely to be included in divorce settlements, fewer than one out of seven fathers provides assistance on a very regular basis. Results based on a different scale indicate that more fathers have at some time paid child support (almost three out of four) than have at some time provided any of the other forms of assistance. ${ }^{1}$

Fathers are somewhat more likely to provide economic assistance than non-economic assistance. The proportion of fathers who participate in the schooling of their children is

1. Originally, two measures of receipt of child support were considered: whether support was received in the past month and the regularity with which support is received. Each indicator is subject to different sorts of response error. While the indicator of whether support was received in the last month is likely to suffer from recall bias, the indicator of the regularity of receipt of support more accurately captures fluctuations over time in the father's propensity to make support payments. There is little substantive difference in results when using the two measures. 
particularly low. Fewer than one father out of 27 regularly assists his children with homework or attends school events. Over 75 percent of divorced fathers have never participated in the schooling of their children. Slightly more fathers (one out of 12) take their children on vacation, while a majority of fathers (three out of five) have purchased gifts.

Because it is possible for fathers to provide only a subset of the types of assistance being considered, the data in Table 2 likely underestimate the percentage of fathers who have ever

Table 2 - Percent of Fathers Making Different Numbers of Contributions

\begin{tabular}{lcc}
\hline $\begin{array}{l}\text { Number of Different } \\
\text { Contributions Made }\end{array}$ & $\begin{array}{c}\text { Excluding Child } \\
\text { Support Payments } \\
\text { (percent) }\end{array}$ & $\begin{array}{c}\text { Including Child } \\
\text { Support Payments } \\
\text { (percent) }\end{array}$ \\
\hline None & 31 & 19 \\
One & 10 & 16 \\
Two & 12 & 10 \\
Three & 11 & 11 \\
Four & 9 & 10 \\
Five & 6 & 8 \\
Six & 6 & 6 \\
Seven & 5 & 6 \\
Eight & 11 & 8 \\
Nine & - & 6 \\
\hline
\end{tabular}

provided any type of assistance. The data in Table 3 address this possibility by presenting the percentage of fathers who have ever provided different numbers of contributions. The first column of figures excludes child-support payments, while the second column of figures includes them. More fathers have at some time provided at least one type of assistance than is evident from considering each type separately. Excluding child support, about two out of three fathers have made one or more types of contributions, while including child support, this figure increases to about four out of five fathers. Note, however, that these figures refer to having ever provided assistance-the percentage of fathers that provide assistance on a very regular basis would be much smaller. Moreover, the fact that one out of five fathers has never provided any of the types of assistance speaks to the frailty of father-child relationships outside of marriage.

\section{Explaining Fathers' Contributions}

\section{Expected Relationships}

The multivariate analysis is designed to identify the key correlates of the provision of various forms of support and to ascertain whether fathers who provide a given form of assistance are more likely to make other contributions. The expected correlates of support are suggested by a framework developed by Weiss and Willis (1985). This framework, building on a microeconomic model of the family (Becker 1981), holds that both parents value their children and each therefore benefits from the other's investments in the children. In a two-parent family, propinquity generally acts to maximize the investments of both parents, so that either parent enjoys investments in a child, while also making such investments. After divorce, however, fathers lose control over the allocation of goods and services in the children's household and cannot assume that their economic contributions will be distributed as they wish between the private consumption of the mother and the children. 


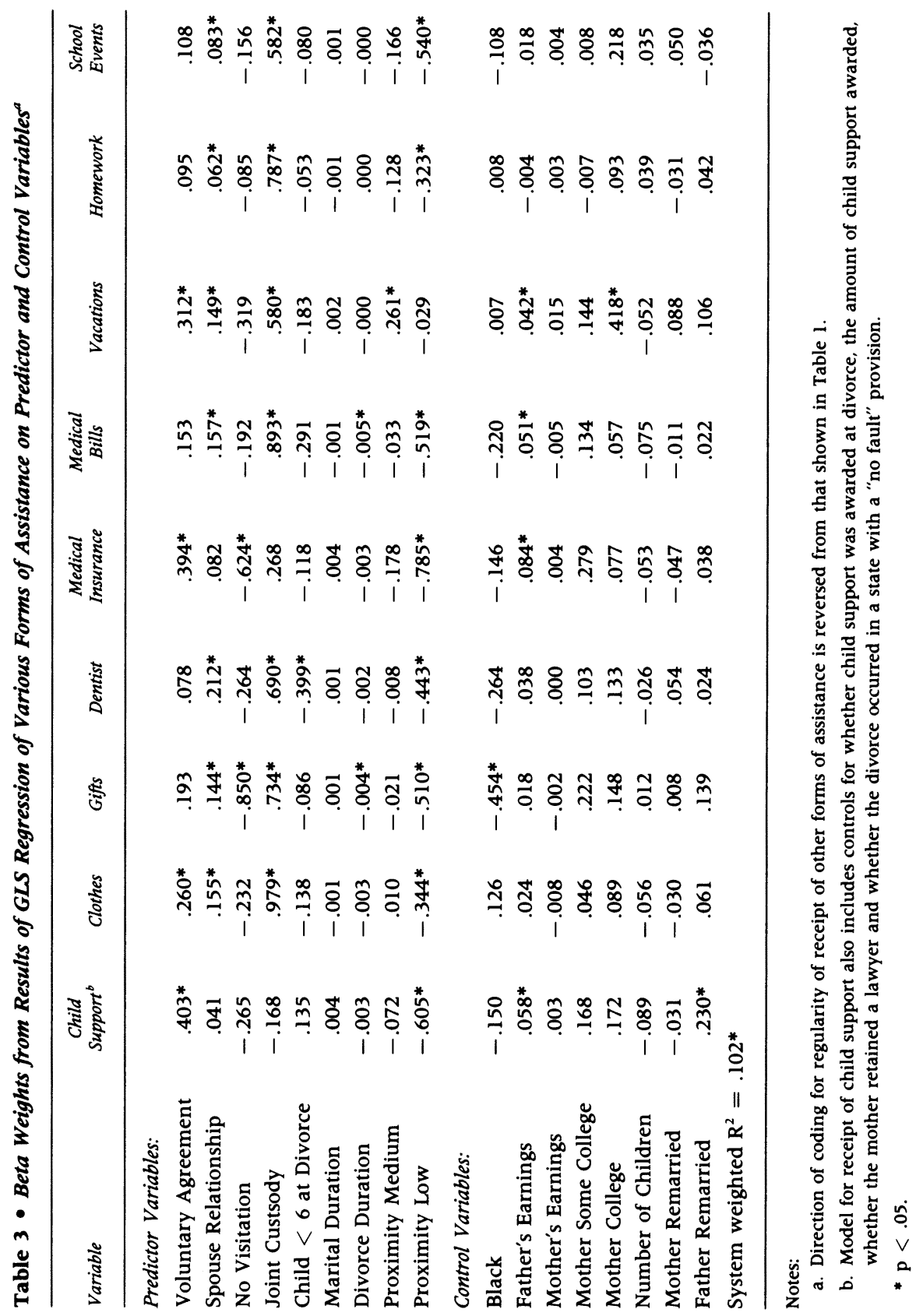


Within this framework, a divorced father is expected to contribute more to his children if he expects greater utility from making contributions than not. The level of utility is based on the costs and rewards associated with providing contributions. Thus, there is a close link between the notion of utility maximization within the microeconomic framework and several variants of exchange theory (Nye 1979). In this paper, the costs and rewards of providing contributions are assumed to be a function of two factors: (1) the degree of emotional and instrumental interdependency between the father and his children and (2) the quality of the relationship between the parents.

Stronger interdependency between fathers and children increases utility by elevating satisfaction in fulfilling such interdependencies by providing different types of assistance. In turn, a good relationship between the divorced parents may increase utility by increasing interdependencies. It is also likely, though, that a better relationship between parents increases utility by increaseing the father's control over how his contributions are allocated.

The strength of interdependency between fathers and their children is measured by the following variables: age of the children at divorce, whether visitation rights were granted, the father's physical proximity, and the time since the divorce. Age of the children at divorce is used to indicate the time fathers had with their children to make economic and emotional investments leading to interdependency. Both mothers and fathers are more likely to agree to visitation rights if the father-child interdependence is strong. Physical proximity, while indicating the opportunity to provide particular forms of assistance (e.g., help with homework), also measures the opportunity to maintain emotional and instrumental interdependency through contact. Time since divorce indicates the erosion of interdependency that occurs as fathers and children develop other interests and responsibilities. It is expected that fathers with older children at divorce, who have visitation rights, who live closer to their children, and who have been divorced for less time will be more likely to make contributions to their children.

The nature of the relationship between parents is measured by the several variables: marital duration, whether the divorce agreement was reached voluntarily, and the mother's report of the quality of the relationship (from bitter to friendly) between the parents during the divorce. Longer marriages, through greater economic and emotional investments, are likely to reflect stronger interdependency between mothers and fathers. The divorce settlement is more likely to be reached voluntarily when the parental relationship is of better quality. A more direct measure of the quality of the parental relationship, although limited to the time of divorce, is the mother's report of how friendly she was with the father during the divorce. It is therefore expected that fathers who were married longer, who entered into a voluntary divorce agreement and who enjoyed a better relationship with the mother during the divorce will be more likely to provide various forms of assistance to their children.

The custody arrangement parents made for their children at divorce is also included in the analysis. Although still relatively rare, the prevalence of joint physical custody has been increasing (Seltzer 1991)-in the NLS sample about 10 percent of the mothers report that fathers have joint custody of their children. Joint custody is more likely to occur when the parents enjoy a reasonably good relationship and when fathers and children are more interdependent. As such, it is anticipated that fathers with joint custody will be more likely to make various contributions to their children. However, the nature of joint custody requires that its effect be evaluated somewhat differently from the effects of other variables. By the very nature of the custody arrangement, resources are provided to children simply by sharing households so that the effect of joint custody on the degree to which fathers contribute to their children is likely inflated and must be interpreted cautiously.

The multivariate analysis also contains a number of control variables that might mitigate the relationship among the covariates discussed above and the provision of various types of 
assistance. These controls include: the socioeconomic resources of parents (measured at divorce), the current marital status of each parent, the number of children, and race. ${ }^{2}$ The socioeconomic resources of the parents are included in order to control for the overall ability of parents to provide for their children. ${ }^{3}$ The number of children is included to control for differences in level of household expenses faced by custodial mothers introduced by variations in household composition. The remarriage of either parent is included to control for changes in interdependency that take place as allegiances are shifted to a new family and new boundaries are erected between the father and his children from the first marriage. Race is included as a control on the basis of research that indicates that black mothers (at least among women who are ever married) are less likely to receive child-support payments from the father (Beller and Graham 1985).

\section{Statistical Model}

The multivariate analysis is conducted using a simultaneous equation procedure in which each type of assistance is made jointly dependent and errors are allowed to be correlated across equations. This is sometimes known as a "seemingly unrelated equations model" (Pindyck and Rubinfeld 1981). The model is appropriate when the dependent variables are conceptually related. It is hypothesized that making child-support payments and providing other forms of assistance are interrelated. Consequently, it is expected that the error terms across the models for each type of assistance will be correlated. As indicated below, the expected direction of the correlations across error terms will vary according to whether one hypothesizes that fathers use various forms of assistance as either supplements to or substitutes for each other.

The model estimated takes the following general form:

$$
\begin{aligned}
& Y_{1}=X_{1} \beta_{1}+\epsilon_{1} \\
& Y_{n}=X_{n} \beta_{n}+\epsilon_{n}
\end{aligned}
$$

where $Y_{1}, \ldots, Y_{n}$ are the forms of assistance provided by fathers, including child support, $X_{1}$, $\ldots, X_{n}$ are vectors of predictor variables that may overlap, $\beta_{1}, \ldots, \beta_{n}$ are vectors of parameters associated with the predictor variables and $\epsilon_{1}, \ldots, \epsilon_{n}$ are error terms with $\operatorname{Cov}\left(\epsilon_{\mathrm{i}}, \epsilon_{\mathrm{j}}\right)$ not restricted to equal 0 . The model is estimated using a two-step, generalized least squares procedure (PROC SYSLIN in SAS).

The regularity with which child support and each of the eight other forms of assistance are provided constitute the dependent variables. ${ }^{4}$ The relationships between providing the

2. Because the marital status of each parent is determined from responses provided by mothers, there is likely to be error in measuring whether the father has remarried. For the approximately 20 percent of mothers who stated that they did not know the marital status of the father, the cases are coded in the zero category (father not remarried). Similarly, when the father's location is not known, the proximity is coded as low. Preliminary analyses indicated that including separate indicators for whether the mother knew the location and marital status of the father does not lead to a better fitting model and does not affect the parameter estimates for other variables.

More generally, there is missing data on several of the predictor variables included in the regression models. The procedure used to handle missing data was to code the mean value of the variable and include a set of dummy variables in preliminary models indicating whether a substitution was made. In none of the preliminary models did the missing data indicators lead to a substantially better fitting model or one that yielded substantively different results.

3. There are two reasons for including the earnings of parents measured at the time of divorce. First, and most important, the NLS does not contain a measure of the father's income following divorce. Second, it is likely that variations in earnings potential are reasonably well captured by earnings at divorce, especially given the relatively short period covered by the NLS data. The education of fathers is not included in the model because of its collinearity with his income and the education and income of mothers.

4. The use of an ordinal scale to measure the regularity with which types of assistance are provided may lead to biased estimates of coefficients when GLS regression is used. However, least squares regression is generally robust to departures from normality. To obtain some idea of the robustness of the GLS results, a logistic regression model was 
various forms of support are indicated by the correlations between the error terms of the model. Positive correlations indicate that fathers who provide at least one type of support are also more likely to provide other types of assistance. Negative correlations indicate that fathers substitute types of support.

\section{Results}

The results from estimating the equations for fathers' contributions are presented in Table 4. ${ }^{5}$ While there are some minor variations in effects across forms of assistance (some of which

Table 4 - Cross-model Correlations for Dependent Variables ${ }^{a}$

\begin{tabular}{|c|c|c|c|c|c|c|c|c|c|}
\hline Variable & $\begin{array}{l}\text { Support } \\
\text { Received }\end{array}$ & Clothes & Gifts & Dentist & $\begin{array}{l}\text { Medical } \\
\text { Insurance }\end{array}$ & $\begin{array}{c}\text { Medical } \\
\text { Bills }\end{array}$ & Vacations & Homework & $\begin{array}{l}\text { School } \\
\text { Events }\end{array}$ \\
\hline $\begin{array}{l}\text { Support } \\
\text { Received }\end{array}$ & 1.00 & & & & & & & & \\
\hline Clothes & .14 & 1.00 & & & & & & & \\
\hline Gifts & .28 & .58 & 1.00 & & & & & & \\
\hline Dentist & .20 & .49 & .42 & 1.00 & & & & & \\
\hline $\begin{array}{l}\text { Medical } \\
\text { Insurance }\end{array}$ & .33 & .35 & .43 & .56 & 1.00 & & & & \\
\hline $\begin{array}{l}\text { Medical } \\
\text { Bills }\end{array}$ & .25 & .51 & .37 & .67 & .52 & 1.00 & & & \\
\hline Vacations & .24 & .52 & .52 & .41 & .35 & .38 & 1.00 & & \\
\hline Homework & .03 & .52 & .36 & .36 & .28 & .41 & .39 & 1.00 & \\
\hline $\begin{array}{l}\text { School } \\
\text { Events }\end{array}$ & .15 & .52 & .42 & .37 & .29 & .39 & .35 & .66 & 1.00 \\
\hline
\end{tabular}

Note:

a. All correlations except that between support received and homework are significant at $p<.05$.

would be expected due to chance), the general pattern is clear. Consistent with the expectations outlined above, fathers who enjoyed a friendlier relationship with the mother during the divorce (for all forms of assistance except child support and medical insurance) and who reached an agreement on the divorce settlement voluntarily (for child support, clothes, medical insurance, and vacations) more regularly contribute to their children. The effect of propinquity is particularly strong-fathers who live farthest from their children are the least likely to provide assistance (vacations being the one exception). Time since divorce is negatively related to the provision of gifts and the payment of medical bills.

Also as expected, fathers who share joint custody of their children are more likely to provide assistance than fathers not sharing custody (medical insurance and child support being exceptions), although the magnitude of the effects indicate that fathers with joint custody do not uniformly contribute to their children on a very regular basis. That joint custody does not affect the payment of child support is not unexpected given the sharing of costs that most

fitted to each of the forms of assistance separately using $l$ to indicate that the assistance had ever been received and $O$ otherwise. The results (not shown) correspond closely to those shown in Table 4.

5. Several additional models were also estimated due to the possibility that the ambiguous time reference of several questions used in the NLS-72 introduces endogeneity (e.g., providing assistance influences the values taken by the covariates). Specifically, it is possible that endogeneity biases the effects of proximity of the father and the marital status of the parents. Using a stepwise procedure to enter these variables in various orders does not alter the pattern of results for other covariates. Possible endogeneity is not explicitly modeled, because this paper is less interested in partitioning the direction of causality and more interested in determining whether a relationship holds. Moreover, there is also concern for the change in the effects of other variables once the additional variables are included. 
likely occurs under this custody arrangement and the resulting latitude that parents have in structuring if and when one parent will make a monetary compensation to the other parent (Seltzer 1991).

Neither the age of the children at divorce nor marital duration has a consistent effect on making contributions. While this may truly be the result of null effects, it should also be noted that the age of children and marital duration are highly collinear (which is exacerbated by the fact that a single cohort of young women is being examined). Indeed, the strength of the collinearity led to the use of a simple dichotomy for the age of children at divorce (at least one child less than age 6). However, other results (not shown) indicate that neither marital duration nor a continuous indicator of the age of children at divorce have significant effects when the other is left out of the model.

Most of the control variables shown in Table 3 have only modest effects on the father's contributions. Higher income fathers are more likely to pay child support, carry medical insurance, and pay for uninsured routine medical bills but are not more likely to provide other forms of assistance. Neither the economic and educational resources of the mother nor the number of children have a consistent effect on contributions from the father. The marital status of mothers and fathers has little effect on whether fathers provide assistance to their children except that remarried fathers are more likely to make child-support payments.

The positive effect of the father's remarriage on the payment of child support is contrary to the expectation outlined earlier in the paper but is consistent with other reports (Beller and Graham 1985; Hill 1984). It may be that fathers who remarry are more family oriented than are fathers who do not remarry, leading to the positive impact on child-support payments. The failure of remarried fathers to provide other forms of assistance may be attributed to the demands on their time and resources made by their new families.

The cross-model correlations for the equations, shown in Table 4, are all positive (and statistically significant with one exception), indicating that fathers who provide at least one form of assistance for their children are more likely to provide other forms of assistance. Note, however, that the correlations between paying child support and providing other contributions are generally smaller than those observed between other pairs of support (the correlations between support received and both assisting with homework and attending school events are very small). On one hand, this suggests that a proportion of fathers restrict the transfer of resources to making child-support payments. On the other hand, these results indicate that if fathers contribute more than just child-support payments, they are likely to provide several types of assistance.

To examine both of these possibilities in greater detail, the extent to which fathers provide more than one form of assistance to their children, conditional on having ever provided a given type of assistance, is shown in Table 5. The mean number of other forms of support ever provided is indicated according to whether each type of assistance has at one time been provided. For most forms of assistance, fathers who have at one time provided the assistance in question have provided between five to six other types of assistance (including the type of support being considered). Of particular note is the number of other types of support provided by fathers who help their children with homework or attend school events. Although these forms of assistance are relatively rare (see Table 1), the fathers that do provide this sort of support make a substantial number of other contributions.

At another extreme, a few other forms of assistance are provided by fathers who have ever paid child support (3.31). This value is much smaller than comparable figures for other forms of assistance and occurs because a substantial proportion of fathers, about 20 percent (data not shown), make child-support payments but do not provide other types of assistance. That is, the mean number of other forms of assistance provided by fathers who make childsupport payments is weighted downward by the proportion of fathers who make child-support payments but provide no other contributions to their children. 
Table 5 - Mean Number of Other Forms of Assistance Ever Provided by Fathers According to Whether Each Type of Assistance Has Ever Been Provided

\begin{tabular}{lcc}
\hline & \multicolumn{2}{c}{ Mean number of other forms of assistance } \\
\cline { 2 - 3 } Variable & Ever Provided & Never Provided \\
\hline Child-Support Payments & 3.31 & 1.35 \\
Clothes & 5.54 & 1.20 \\
Gifts & 4.41 & 0.35 \\
Dentist & 6.30 & 1.44 \\
Medical Insurance & 5.23 & 1.15 \\
Medical Bills & 6.32 & 1.50 \\
Vacation & 5.41 & 1.30 \\
Homework & 6.87 & 1.88 \\
School Events & 6.10 & 1.54 \\
Mean number of forms of assistance provided: & & 2.86 \\
\hline
\end{tabular}

Note: All differences between value for ever provided and never provided are significant at $p<.05$.

Table 6 - Results of OLS Regression of Number of Contributions made by Fathers on Predictor Variables and Controls

\begin{tabular}{lcc}
\hline Variable & $\begin{array}{c}\text { Excluding Child } \\
\text { Support Payments }\end{array}$ & $\begin{array}{c}\text { Including Child } \\
\text { Support Payments }\end{array}$ \\
\hline Predictor Variables: & Beta & Beta \\
Voluntary Agreement & $.731^{*}$ & $.877^{*}$ \\
Spouse Relationship & $.260^{*}$ & $.273^{*}$ \\
No Visitation & $-.902^{*}$ & $-1.188^{*}$ \\
Joint Custody & $1.133^{*}$ & $.929^{*}$ \\
Child < 6 at Divorce & -.251 & -.190 \\
Marital Duration & .006 & .006 \\
Divorce Duration & -.004 & -.004 \\
Proximity Medium & $-.498^{*}$ & $-.498^{*}$ \\
Proximity Low & $-1.644^{*}$ & $-1.862^{*}$ \\
Control Variables: & & \\
Black & -.167 & -.288 \\
Father's Earnings & $.089 *$ & $.108^{*}$ \\
Mother's Earnings & -.019 & -.018 \\
Mother Some College & .224 & .297 \\
Number of Children & -.256 & -.278 \\
Mother College & .469 & .507 \\
Mother Remarried & -.223 & -.239 \\
Father Remarried & .204 & .291 \\
R & $.23 *$ & $.25 *$ \\
\hline & &
\end{tabular}

Notes:

a. Direction of coding for regularity of receipt of other forms of assistance is reversed from that shown in Table 1.

* $\mathrm{p}<.05$. 
The multivariate analysis is concluded by considering the predictors of the number of different contributions ever made by fathers. Because the cross-model correlations shown in Table 4 and the means shown in Table 5 indicate that fathers who provide at least one type of assistance are more likely to provide other contributions, it is expected that the predictors of the number of contributions ever made will be similar to those for the regularity with which individual types of assistance are provided. As shown in Table 6, the pattern of effects for the number of different contributions made by fathers is indeed very similar to that observed in Table 3. Fathers who voluntarily agreed to the divorce settlement, who enjoyed a friendlier relationship with their spouse during the divorce, who live closer to their children, who earn more, who have visitation rights and who have joint custody all provide a greater number of contributions. Thus, the factors that lead fathers to make at least one type of contribution more regularly also act to increase the diversity of the types of contributions they provide to their children.

\section{Discussion}

Using data from a nationally representative sample, I have examined the extent to which divorced fathers contribute to their children, ranging from clothes to help with homework. Other than paying child support and buying gifts, the majority of fathers have never provided assistance to their children. Consistent with other studies which show that divorced fathers have little contact with their children (Furstenberg et al. 1983), fathers are particularly unlikely to provide assistance that requires their direct participation (e.g., helping their children with homework or attending school events).

The picture is less dramatic but still telling when considering the percent of fathers who have at one time provided at least one type of assistance. Other than paying child support, about one out of three fathers has never provided assistance to their children. Considering both child-support payments and other forms of assistance, about one out of five fathers has never provided any form of assistance. While these figures show that a majority of fathers have provided at least some form of assistance to their children, they also indicate that a substantial minority have never contributed to their children (at least with respect to the forms of assistance considered in this paper). Moreover, the figures refer to having ever provided assistance, ignoring the regularity with which contributions are made. For example, none of the fathers in the NLS sample has provided each of the types of support on a very regular basis (data not shown). Including child-support payments, only 50 percent of the fathers have provided at least one type of assistance on a very regular basis (data not shown).

One consequence of this pattern is that children from disrupted families are more likely to experience some form of deprivation than children from intact families. Subsequent research needs to more clearly document the parameters of this deprivation, its long term consequences, and the role of various types of contributions from fathers in alleviating deprivation. It would also be useful to obtain a better understanding of the socioemotional consequences for children of variations in the nature and extent of contributions made by fathers.

While not the central focus of this paper, the effect of joint custody on the provision of assistance is also interesting to note. With the exception of paying child support, it is clear that fathers who share physical custody of their children are more likely to transfer resources to their children. Although this may occur because joint physical custody increases the participation of fathers in rearing their children, such a conclusion must be made with a significant caveat. Under the current regime of divorce settlements, parents who agree to a joint custody arrangement are likely to be an unusually select subset of all parents (as noted above, in the NLS data, joint custody arrangements characterize only about 10 percent of the divorces). 
Attempts to unilaterally increase the prevalence of joint physical custody could result in rapidly diminishing returns in terms of the father's contribution. It remains an open question as to the nature and extent of this selectivity problem-but a question that is crucial for the development of policy initiatives.

Despite the generally negative tone of the findings, the data indicate that there is a subset of fathers who contribute substantially to their children. Both the cross-tabular and multivariate analyses indicate that fathers who regularly make child-support payments supplement those payments with other forms of assistance. There is no evidence to indicate that various forms of assistance may serve as substitutes for each other.

Finally, the multivariate analysis indicates that objective measures of household socioeconomic status (i.e., mother's education and income, fathers income, number and ages of children) are less important in predicting whether assistance is provided than are indicators of the parental relationship. The development of policy and programs aimed at maximizing the contributions to the children of divorce should consider the role played by the parental relationship.

\section{References}

Becker, Gary

1981 A Treatise on the Family. Cambridge, Mass.: Harvard University Press.

Beller, Andrea, and John Graham

1985 "Variations in the economic well-being of divorced women and their children." In Horizontal Equity, Uncertainty and Economic Well-Being, Studies in Income Wealth Series, Vol. 50, ed. Martin David and Timothy Smeeding, 471-506. Chicago: University of Chicago Press.

1986 "Child support awards: Differentials and trends by race and marital status." Demography 23:231-246.

Furstenberg, Frank, Christine Nord, James Peterson, and Nicholas Zill.

1983 "The life course of children of divorce: Marital disruption and parental contact." American Sociological Review 48:656-667.

Garfinkel, Irwin, and Sara McLanahan

1986 Single Mothers and their Children. Washington, D.C.: Urban Institute.

Haskins, Ronald

1988 "Child support: The men's view." In Child Support: From Debt Collection to Social Policy, ed. Sheila Kamerman and Alfred Kahn, 306-317. Newbury Park, Calif.: Sage.

Hetherington, E. Mavis, Martha Cox, and Roger Cox

1979 "Play and social interaction in children following divorce." Journal of Social Issues 35:2649.

Hill, Martha

1984 "PSID analysis of matched pairs of ex-spouses: Relation of economic resources and new family obligations to child support payments." Unpublished manuscript, Institute for Survey Research, University of Michigan.

Hoffman, Saul, and Greg Duncan

1988 "What are the economic consequences of divorce?" Demography 25:641-645.

Kahn, Alfred, and Sheila Kamerman

1988 Child Support: From Debt Collection to Social Policy. Newbury Park, Calif.: Sage. Lerman, Robert

1987 Child Support and Dependency. Report prepared for U.S. Department of Health and Human Services under contract No. HHS-CS-86-0021.

Matsueda, Ross, and Karen Heimer

1987 "Attitudes toward women's familial roles: Change in the United States, 1977-1985." American Sociological Review 52:826-840. 
McLanahan, Sara

1985 "Family Structure and the reproduction of poverty." American Journal of Sociology 90:873-901.

McLanahan, Sara, and Larry Bumpass

1988 "Intergenerational consequences of family disruption." American Journal of Sociology 94:130-152.

Nye, F. Ivan

1979 "Choice, exchange and the family." In Contemporary Theories about the Family, ed. Wesley Burr, Reuben Hill, F. Ivan Nye, and Ira Reiss, 1-41. New York: Free Press.

Office of Child Support Enforcement.

1988 Twelfth Annual Report to Congress for the Period Ending September 30, 1987.

Washington, D.C.: Government Printing Office.

O’Neill, June

1985 "Determinants of child support." Report prepared for the National Institute of Child

Health and Human Development under grant No. RO-1-HD-16840.

Peterson, James, and Christine Nord

1988 "The regular receipt of child support: A multi-step process." Unpublished manuscript, Child Trends, Washington, D.C.

Pindyck, Robert, and Daniel Rubinfeld

1981 Econometric Models and Economic Forecasts. New York: McGraw-Hill.

Seltzer, Judith

Forth- "Legal custody arrangements and the intergenerational transmission of economic coming welfare." American Journal of Sociology.

Seltzer, Judith, and Irwin Garfinkel

1990 "Inequality in divorce settlements: An investigation of property settlements and child support awards." Social Science Research 19:82-111.

Seltzer, Judith, Nora Cate Schaeffer, and Hong-wen Charng

1989 "Family ties after divorce: The relationship between visiting and paying child support." Journal of Marriage and the Family 51:1013-1031.

Teachman, Jay

1990 "Socioeconomic resources of parents and the award of child support in the United States:

Some exploratory models." Journal of Marriage and the Family 52:689-700.

Tourangeau, Roger, Penny Sebring, Barbara Campbell, Martin Glusberg, Bruce Spenner, and Melody

Singleton

1987 The National Longitudinal Study of the High School Class of 1972 (NLS-72) Fifth Followup (1972) Data File User's Manual. Chicago: National Opinion Research Center,

University of Chicago.

Weiss, Yoram, and Robert Willis

1985 "Children as collective goods and divorce settlements." Journal of Labor Economics 3:268-292. 
Appendix A - Means and Standard Deviations for Independent Variables

\begin{tabular}{|c|c|c|c|}
\hline Predictor Variables & Values & Mean & $S D$ \\
\hline Voluntary Agreement & $\begin{array}{l}1=\text { Child-support agreement reached voluntarily } \\
0=\text { Otherwise }\end{array}$ & .54 & .50 \\
\hline Visitation & $\begin{array}{l}1=\text { Visitation rights not granted at divorce } \\
0=\text { Otherwise }\end{array}$ & .07 & .26 \\
\hline Child $<6$ at Divorce ${ }^{a}$ & $\begin{array}{l}1=\text { At least one child }<6 \text { at divorce } \\
0=\text { Otherwise }\end{array}$ & .78 & .42 \\
\hline Number of Children & Number of own children at divorce & 1.50 & .70 \\
\hline Duration of Marriage & In months & 70.67 & 37.74 \\
\hline Duration since Divorce & In months & 78.57 & 46.19 \\
\hline Log of Mother's Income & Log of income at divorce in 1985 dollars & 6.94 & 4.10 \\
\hline Mother College ${ }^{b}$ & $\begin{array}{l}1=\text { College degree or higher } \\
0=\text { Otherwise }\end{array}$ & .08 & .27 \\
\hline Mother Some Collegeb & $\begin{array}{l}1=\text { At least some college } \\
0=\text { Otherwise }\end{array}$ & .34 & .47 \\
\hline Log of Father's Income & Log of income at divorce in 1985 dollars & 9.17 & 2.62 \\
\hline Joint Custody & $\begin{array}{l}1=\text { Joint physical custody } \\
0=\text { Otherwise }\end{array}$ & .10 & .30 \\
\hline $\begin{array}{l}\text { Spouse Relationship } \\
\text { During Divorce }\end{array}$ & $\begin{array}{l}1=\text { Bitter } \\
2=\text { Many disputes } \\
3=\text { Some disputes } \\
4=\text { Friendly }\end{array}$ & 2.64 & 1.09 \\
\hline Black & $\begin{array}{l}1=\text { Black } \\
0=\text { Otherwise }\end{array}$ & .14 & .35 \\
\hline Regularity of Support & $\begin{array}{l}1=\text { Never } \\
2=\text { Seldom } \\
3=\text { Occasionally } \\
4=\text { Regularly }\end{array}$ & 2.31 & 1.28 \\
\hline Proximity Medium ${ }^{c}$ & $\begin{array}{l}1=\text { Same state or different state }<500 \text { miles } \\
0=\text { Otherwise }\end{array}$ & .38 & .49 \\
\hline Proximity Low $\mathrm{c}$ & $\begin{array}{l}1=\text { Different state }>500 \text { miles or don't know } \\
0=\text { Otherwise }\end{array}$ & .28 & .45 \\
\hline Mother Remarried & $\begin{array}{l}1=\text { Mother has remarried } \\
0=\text { Otherwise }\end{array}$ & .48 & .50 \\
\hline Father Remarried & $\begin{array}{l}1=\text { Father has remarried } \\
0=\text { Otherwise }\end{array}$ & .53 & .50 \\
\hline
\end{tabular}

Notes: The following variables were used in the equation for making child support payments but not in the equations for the receipt of other forms of support. Mother Retained a Lawyer at Divorce $(1=$ No, $0=$ Otherwise; mean $=.11$, sd $=$ .31); Divorce Occurred in "No Fault State" ( $1=$ Yes, $0=$ Otherwise; mean = .71, sd =.46); Child Support was Awarded at Divorce $(1=$ Yes, $0=$ Otherwise; mean $=.81, \mathrm{sd}=.39)$; Log of Amount of Child Support Awarded at Divorce (In log of 1985 dollars; mean $=4.33$, $\mathrm{sd}=2.29$ ).

a. Age of children at divorce is dichotomized because of the high degree of collinearity with marital duration. Age 6 was used as the age for dichotomization because this is the age at which children begin attending school.

b. Mother's education at divorce was reported in categories. Dummy variable coding is used to capture potential nonlinearities in the effect of education.

c. Father's location was reported in categories that only allow dummy variable coding. 